\title{
O ENSAIO COMO REVOLTA EM THEODOR ADORNO
}

\author{
GABRIELA NASCIMENTO SOUZA ${ }^{1}$ \\ O ensaio como revolta em Theodor Adorno
}

RESUMO: O presente artigo pretende compreender o ensaio em Theodor Adorno como uma revolta da filosofia transformada contra a filosofia tradicional. Tendo como ponto de partida a crítica de Adorno à filosofia idealista, nos propomos a instigar uma reflexão a respeito não só do grande avanço e importância da dialética negativa que perpetua o ensaio, mas também dos seus limites.

PALAVRAS-CHAVE: ensaio, revolta, Adorno

\begin{abstract}
The present article aims to undertand the essay in Theodor Adorno as a revolt of transformed philosophy against tradicional philosophy. Taking as a starting point the criticism from Adorno to the idealist philosophy, we propose to instigate a reflexion not just about the great advance and importance of the negative dialectics that perpetuates the essay, but also on its limits.
\end{abstract}

KEYWORDS: essay, revolt, Adorno

Após o fracasso do Iluminismo e com a desmistificação do mundo, ciência e arte separaram-se de forma irreversível. Segundo as reflexões de Adorno, a partir dessa partição histórica o reestabelecimento da unidade perdida entre uma extensa variedade de contrários tornou-se impossível. A filosofia teria insistido nessa reconciliação, entretanto a impossibilidade de concretizar tal unidade na experiência a configurou como um estudo acadêmico e desconexo. Ao estudo acadêmico caberiam apenas os fundamentos últimos e os conceitos mais abstratos, enquanto aos pensadores do cotidiano, a experiência "sem propósito" do transitório. Em um primeiro momento, o ensaio se revolta contra essa tradição filosófica acadêmica. Nesse contexto, a filosofia de Theodor Adorno, que pode ser entendida como uma crítica à sociedade como um todo, tem no ensaio uma crítica no âmbito da filosofia.

O ensaio se revolta contra a ideia de que o efêmero e o transitório não são objetos da filosofia. O ponto de partida para essa revolta é a crítica de Adorno à filosofia da identidade 
própria do idealismo, na qual a verdade antagônica da experiência seria dissolvida na ilusão do infinito e culminaria na ideia dogmática que dá maior dignidade ontológica à abstração. Esse é o ponto central da argumentação que tentaremos traçar aqui. O artigo presente tem como objetivo principal mostrar, ancorado principalmente nas reflexões de Ensaio como forma (2003), em que sentido o ensaio pode ser compreendido como uma revolta protagonizada pela filosofia transformada contra a filosofia tradicional. A fim de dar uma introdução concisa ao nosso objetivo principal, iniciamos o artigo com a crítica de Adorno à filosofia tradicional e apresentamos sua proposta de uma nova filosofia. Seguimos com a explicação de como a revolta está inserida no ensaio e de como o ensaio pode ser entendido como revolta. Evidenciaremos nessa segunda etapa que o ensaio é a forma crítica mais adequada para o fazer de uma nova filosofia e que essa crítica perpetua e está perpetuada pela revolta. O último tópico parte dos reconhecidos avanços da nova filosofia e se apresenta como instigador de uma reflexão a respeito de alguns limites, tanto da crítica de Adorno à filosofia idealista de Hegel, quanto da sua dialética negativa.

\section{A crise da filosofia idealista: o ponto de partida para uma nova filosofia}

É evidente uma nova compreensão do fazer filosófico e da própria filosofia em toda a elaboração teórica de Adorno. Tal compreensão é uma demanda da sociedade fragmentada e da incapacidade da filosofia enquanto disciplina de dar conta dos problemas gerados em meio à cultura burguesa vigente. A separação impossível de reversão entre ciência e arte tem como espelho uma sociedade fragmentada em ramos e setores. Aos indivíduos que constituem essa sociedade uma reflexão que tenha a intenção de unificar ciência e arte, dando a elas uma fundamentação filosófica abstrata, não faz mais sentido. A pretensão da filosofia de explicar a realidade segundo o princípio de identidade entre sujeito e objeto, por exemplo, corresponde à crise da própria filosofia idealista. Em 1931, na conferência A atualidade da filosofia, Adorno profere que:

Quem hoje escolhe o trabalho filosófico como profissão deve de saída renunciar à ilusão com que antes começavam os projetos filosóficos: que seria possível apreender com a força do pensamento a totalidade do real [...] a crise do idealismo é equivalente à crise da pretensão filosófica da totalidade (2000, p.17).

Frente a essa crise surgem os esforços da filosofia científica de solucionar os problemas da filosofia idealista, recorrendo primeiramente ao empirismo ensaísta de Bacon e Hume para abandonar a questão de fundamentação do real em um sistema. Entretanto, a 
fundamentação filosófica do procedimento científico continua sendo um método e, por isso não pode se colocar como crítica ao sistema. Mesmo atribuindo a primazia da experiência sobre a ordem conceitual, as filosofias empiristas permanecem sistemáticas "na medida em que definem condições para o conhecimento, concebidas de um modo mais ou menos constante, e desenvolvem essas questões em um contexto o mais homogêneo possível" (ADORNO, 2003, p.24). Essa corrente atribui validade apenas às ciências da natureza, mas com isso, perde "a relação com os problemas históricos da filosofia" (2000, p.17) e não percebe que suas experimentações estão vinculadas a estes problemas históricos e que não podem solucioná-las independente dos mesmos.

Além disso, na intenção de resgatar a objetividade supostamente perdida pelo idealismo, os empiristas o fazem por meio das características do subjetivismo. Nesse contexto também se apresenta o esforço da fenomenologia de solucionar uma suposta teoria da realidade carente de elementos mais concretos. Os fenomenólogos procuraram, então, dirigirse às coisas mesmas. Adorno parte de uma crítica a Husserl ${ }^{2}$ para fazer de Heidegger a personificação da sua crítica à fenomenologia. Tanto Husserl quanto Heidegger confiaram em demasia na intuição da essência e procuraram fundamentações últimas que transcendem as coisas mesmas às quais eles pretendiam se dirigir. Porém, Heidegger é o principal alvo dessa crítica porque, segundo Adorno, é ele quem ontologizou o ente e impossibilitou tanto a emancipação do sujeito livre quanto a compreensão dos objetos a partir deles mesmos.

Essa ontologização do ente significa que o Ser torna-se uma repetição do ente e que o ente apenas habita o Ser, sendo esse mesmo ente desprovido de tudo que se atribui ao Ser. O ente não reconhece seu caráter ôntico, o ente é ontologizado e torna-se um parasita do Ser ${ }^{3}$. Nesse processo, o sujeito efetua a intuição do Ser de forma passiva, é como se o sujeito, dentro da sociedade, apenas se adequasse a ela sem nenhuma crítica. Seguindo as intenções proferidas por Adorno e Horkheimer na Dialética do Esclarecimento, a filosofia de Heidegger se apresenta como uma "pedra no caminho" da filosofia crítica que deve ser removida. Se uma das principais intenções dessa obra situa-se na emancipação do sujeito frente à dominação promovida por ele mesmo, não há possibilidade de se reportar ao sujeito como simplesmente passivo.

No que se refere à impossibilidade da compreensão dos objetos a partir deles mesmos, a filosofia de Heidegger tem no conceito de Ser a impossibilidade do mediado. O conceito de Ser em Heidegger é explicado por uma tautotologia, no sentido que não é nada além dele mesmo em sua imediatidade. Ser não é apreensível por conceitos, e sendo desprovido de 
mediação, ele também é desprovido de qualquer instância crítica, apenas "repetição do puro nome" (ADORNO, 2009, p.68). O Ser de Heidegger tem um acesso imediato, e essa é a arbitrariedade da suposta pureza do Ser, uma vez que a sua pureza evidenciaria "exatamente o contrário de uma pura imediatidade, a saber, algo inteiramente mediado, que apenas ganha sentido na mediação" (HAAG, 1960, p.73. In: ADORNO, 2009, p.67). Para Adorno, assim como para Hegel, "não há nada entre o céu e a terra que não seja mediado" (ADORNO, 2003, p.40). Nesse sentido, o próprio conceito de Ser é uma presa da mediação que perpetua a crítica ao imediato a cada momento em que a abordagem da imediatez se faz presente. Para Adorno, o Ser de acesso imediato é apenas pré-filosófico, a mediação que captura e destrincha a imediatez é a forma crítica e propriamente filosófica.

Ao tentar uma resposta melhor do que a que foi desenvolvida pelo empirismo e posteriormente pelo positivismo para o idealismo, Heidegger nos envolve em seu jargão de autenticidade. Esse jargão consiste na em uma "ambiciosa transcendência da linguagem para além do sentido" que "acaba desembocando em um vazio de sentido" (ADORNO, 2003, p.21). Isso significa que ao criticar a resposta positivista ao idealismo, por ela ser objetiva demais e perder o sentido, Heidegger cai na sua própria crítica, porque sua linguagem ainda “ousa mover-se no âmbito das ciências" (ADORNO, 2003, p.21) ${ }^{4}$.

Para Adorno a filosofia transformada tem de capturar aquilo que é desprezado pelo conceito por meio do próprio conceito e de seu movimento de mediação. Isso significa que os idealistas, os fenomenólogos e até mesmo os ensaístas empíricos foram incapazes de apreender a realidade dos fenômenos, ou porque confiaram demais no éter, ou porque partiram de princípios originários para dar às coisas categorias abstratas que as transcendem ou, e talvez principalmente, porque dissimularam a essência fragmentada e antagônica das coisas e dos conceitos. É preciso desencantar o conceito e o trazer para sua esfera heterogênea, enfrentando a utopia do conhecimento de "abrir o não conceitual com conceitos, sem equipará-lo a esses conceitos" (ADORNO, 2009, p.17). Nesse enfrentamento Adorno apresenta à tese da identidade idealista, que tem como fundo a apresentação da verdade e da inverdade dos conceitos em contraponto a seu teor de verdade unilateral ${ }^{5}$.

O paradoxo atribuído ao conceito de se dizer o que não pode ser dito é o objeto sobre o qual o trabalho filosófico se empenha. A confiança da filosofia em destrinchar esse paradoxo é ao mesmo tempo imprescindível e prejudicial. Imprescindível porque nos possibilita a compreensão de uma vertente dupla da verdade e prejudicial porque pode nos encaminhar, com os idealistas, a uma tese de identidade que leva ao infinito universal. Segundo Adorno, 
pelo movimento de mediação, os conceitos podem acessar uma parte da verdade das coisas que não está evidentemente nelas. Essa verdade é abstrata e "não pode ter nenhum cenário senão aquilo que o conceito reprime, despreza e rejeita" (ADORNO, 2009, p.17). Assim, o não conceitual aberto pelo conceito consiste na sua inverdade que deve ser equiparada ao próprio conceito como sua verdade. Na dialética idealista, essa verdade corresponderia àquela "que impele para além de todo e qualquer elemento particular como algo falso em sua unilateralidade, seria a verdade do todo; se ela não fosse previamente pensada, os passos dialéticos perderiam sua motivação e direção" (ADORNO, 2009, p.17). A universalidade previamente pensada pelo idealismo é necessária para a constituição de um sistema. Quando não há essa necessidade real, a tese de identidade é rebatida pela tese de não identidade própria do pensamento antissistemático da filosofia crítica de Adorno. A tese da não identidade entre verdade e inverdade, sujeito e objeto, acompanha a impossibilidade de reconciliação entre ciência e arte referida no início deste artigo.

Para Adorno, apesar de ter ido além de Kant no que consiste em desenvolver uma identidade a partir da mediação e não uma identidade falsa e imediata, Hegel persiste na teoria da identidade. A interpretação de Adorno assegura que Hegel reduziria o não idêntico ao idêntico, o particular ao universal, o objeto ao sujeito e que nisso consistiria sua dialética positiva de primazia do todo. Como uma forma de reestruturação da dialética hegeliana, Adorno parece concordar com a ideia de que o conceito não é mais abstração, mas já não o considera como um universal concreto. Em relação à mediação e não imediatidade do conceito Adorno também concorda com Hegel e se difere de Kant, para quem o conceito era apenas uma forma vazia na qual se acrescentam elementos da sensibilidade ${ }^{6}$. Entretanto, enquanto o conceito para Hegel, como não representa o que é dado pela sensibilidade, é a própria totalidade e o final de um processo, o conceito para Adorno não é uma totalidade elevada e superordenada, nem o final de um processo, mas o próprio movimento do pensamento que determina o objeto em seus próprios rastros de dissonâncias indissolúveis.

Segundo Adorno, a compreensão do conceito em Hegel violenta o mundo da experiência, uma vez que o adequa a manifestação sistemática da totalidade. Nesse contexto se evidencia a insuficiência do conceito para lidar com a experiência, porque a experiência é sempre um antagonismo que não permite reduzir seus contrários a uma identidade. " $O$ pensamento identificador, a igualação de todo e qualquer desigual, perpetua-se no medo da sujeição a natureza que se subtrai a dominação. Por agora, a razão está padecendo: curar-se de um tal mal é que seria propriamente razão" (2009, p.149). Aqui a crítica de Adorno a Hegel se 
alia a crítica de Adorno a Kant, a qual consiste basicamente na ideia de que o desenvolvimento de uma sociedade emancipada pela operação de uma subjetividade esclarecida levou a radicalização da razão como constituição da humanidade pela fundamentação de si mesma e a dissolveu num mecanismo bárbaro de dominação ${ }^{7}$.

Toda essa abordagem inicial se configura como um resumo elucidativo da compreensão adorniana do fracasso dos esforços da filosofia em desenvolver um pensamento grande e total. A crise da filosofia idealista é tomada como ponto de partida para o nascimento de uma filosofia que deve proceder "interpretando cada vez mais com a pretensão da verdade, sem possuir uma chave segura para a interpretação". A filosofia deve encarar a realidade como interpretativa e não como algo de pleno sentido, porque a filosofia que se conecta com a experiência não busca pelo sentido. Com os pés no chão, a filosofia não aceita mais o dualismo entre o mundo e o seu outro, entre o inteligível e o empírico, ela não procura por uma verdade oculta localizada atrás dos fenômenos. A autêntica interpretação se conecta com o materialismo no sentido de que é desprovida de intenção e se empreende em combinar os elementos separados existentes num mesmo objeto. Esse programa pertencente ao conhecimento materialista permite que a interpretação se debruce sobre o texto que a filosofia tem que ler, que é: "incompleto, contraditório e fragmentário e grande parte dele pode estar entregue a cegos demônios" (ADORNO, 2000, p.17). Esse texto é o ensaio.

\section{O ensaio como revolta e a revolta no ensaio}

As considerações do tópico anterior permitem apresentar o ensaio como um protesto a favor da libertação da dialética positiva. Esta, que movimenta o sistema, se perpetua em três passos, a afirmação, a negação e a negação da negação. A dialética negativa, que movimenta o ensaio, vai apenas até o segundo passo e constitui seu movimento no próprio conflito. Nesse sentido, a dialética negativa é intrínseca ao movimento conceitual do ensaio, porque o ensaio é antissistemático e não admite que o seu assunto seja destrinchado até o fim. As coisas são conflituosas em si mesmas, a tentativa de resolver ou dissolver a negação intrínseca das coisas por uma suposta negação da negação (síntese) é a ilusão de dissolver as contradições num infinito.

Segundo Adorno, os idealistas usaram a palavra infinito para acabar com a mísera finitude do seu aparato. A filosofia idealista acreditou possuir um objeto infinito e disso ocorreu que a filosofia tornou-se finita, conclusiva e, portanto, adequada a um sistema 
perfeito. Uma filosofia transformada, ao contrário, não se enquadra a nenhum esquema e tem seu conteúdo na multiplicidade. Adorno diz que ela "não seria outra coisa senão a experiência plena" (2009, p.20). A relação com a experiência, tão substancial para o ensaio, é uma relação com toda a história. Desta forma, as separações entre experiência da humanidade histórica (mediada) e experiência individual (imediata); filosofia primeira e filosofia da cultura; temporal e atemporal, não são sustentadas pelo ensaio.

O ensaio se revolta contra os dualismos decorrentes da filosofia tradicional, assim como contra toda e qualquer tentativa de dar um fundamento último para a filosofia. $\mathrm{O}$ ensaio é a nova filosofia em estado de revolta contra o idealismo, contra o empirismo, contra o positivismo, contra a fenomenologia e também contra o racionalismo. A nova filosofia, protagonizada pelo ensaio, só existiria como revolta, porque a revolta contra os sistemas existentes e contra a supremacia da abstração é uma das suas condições de possibilidade. Com isso, também podemos dizer que a revolta está enraizada na forma, no conteúdo e na própria metodologia sem método do ensaio.

O texto de Adorno, publicado em 1974 e já por nós citado, O ensaio como forma, inicia declarando o mal-estar do ensaio na Alemanha devido à resistência da academia em levar em consideração sua reflexão. Como já dito, ciência e arte teriam se separado de forma irreversível após a desmistificação do mundo, mas algumas filosofias continuaram insistindo em unificar esses âmbitos. A filosofia do jovem Lukács é uma delas, e segundo essa reflexão, falta ao ensaio o que a literatura teria conseguido realizar, a saber, o distanciamento do caminho que leva à autonomia e o desenvolvimento "a partir de uma primitiva e indiferenciada unidade com a ciência, a moral e a arte" (LUKÁCS, 1911, p.29 In: ADORNO, 2003, p.15). Para Adorno, o ensaio não pode ser entendido dessa maneira, ele não tem nada a ver com a unidade primitiva, nem:

[...] admite que seu âmbito de competência lhe seja prescrito. Em vez de alcançar algo cientificamente ou criar artisticamente alguma coisa, seus esforços ainda espelham a disponibilidade de quem, como uma criança, não tem vergonha de se entusiasmar com o que os outros já fizeram. O ensaio reflete o que é amado e odiado (ADORNO, 2003, p.16).

O ensaio reflete os antagonismos que brotam da experiência e que estão intrinsecamente nos objetos. Por isso ele não tem um ponto de partida preestabelecido, ele não é uma criação a partir do nada, sequer uma criação a partir de alguma coisa. O seu único propósito, se é que podemos falar em propósito quando não existe um fim último, é a filosofia interpretativa. $\mathrm{O}$ ensaio fere a pretensão iluminista de liberdade com uma liberdade realizável para além da formalidade, pela interpretação da realidade fragmentada e antagônica. Os 
critérios do ensaio são, portanto, "a compatibilidade com o texto e com a própria interpretação e também a sua capacidade de dar voz ao conjunto de elementos do objeto" (ADORNO, 2003, p.18).

Esse mergulho profundo na experiência impede que o ensaio pense na verdade e na história como duas vertentes separadas e irreconciliáveis. Isso significa que, com Hegel e contra Kant, o a posteriori torna-se um a priori porque "a experiência meramente individual, que a consciência toma como ponto de partida por sua proximidade, é ela mesma já mediada pela experiência mais abrangente da humanidade histórica" (ADORNO, 2003, p.26). A ideia tradicional de verdade é colocada em cheque pelo ensaio, o eterno e o transitório não são mais como duas moedas diferentes, mas consistem em dois lados cambiantes de uma mesma moeda.

$\mathrm{Na}$ revolta contra a concepção de verdade imutável e segura, o ensaio desafia o método e elege, em contrapartida, a experiência intelectual como seu modelo. Por experiência intelectual Adorno entende a submissão do ensaio à mediação dos conceitos em meio a um pensamento que não corresponde a um contínuo de operações que avança em sentido único, mas sim aos variados momentos que se entrelaçam como numa grande teia. Por isso, "o pensador, na verdade, nem sequer pensa, mas sim faz de si mesmo o palco da experiência intelectual, sem desmaranhá-la" (ADORNO, 2003, p.30). Essa operação não parte de regras pré-determinadas, ela mergulha no campo de luta dos contrários que constituem o próprio conceito e que o movimentam. A experiência intelectual consiste no proceder do ensaio que é, "por assim dizer, metodicamente sem método" (2003, p.30).

Já em 1964, antes mesmo de desenvolver a Dialética Negativa (1966), Adorno escreve em Observações sobre o pensamento filosófico, sobre a constelação ${ }^{8}$ conceitual, na qual os conceitos e objetos não aceitam adequação a pressupostos metodológicos. O pensar já consiste no movimento de entrelaçamento dos conceitos e é em si a própria experiência intelectual, a partir da qual os elementos que aparecem distanciados vão mostrando suas integrações e, sendo assim, não podemos dizer que os textos ou objetos são coisas criadas, mas sim, iluminadas pelo movimento do próprio conceito. Nas palavras de Adorno: "O pensar não deve reduzir-se ao método [...] deve levar em conta sua intervenção e sua experiência na construção do objeto" (1995, p.19). Esse procedimento, comparado ao aprendizado de uma língua na sua própria terra, que não parte das regras gramaticais ou de significado ensinadas na escola, é consequentemente exposto ao erro. Por isso também que o ensaio desafia a certeza do método e configura uma intenção utópica. 
O ensaio não apenas negligencia a certeza indubitável, como também renuncia ao ideal dessa certeza. Torna-se verdadeiro pela marcha de seu pensamento, que o leva para além de si mesmo, e não pela obsessão em buscar seus fundamentos como se fossem tesouros enterrados (ADORNO, 2003, p.30).

É justamente nesse sentido que, segundo Adorno, o ensaio "deveria ser interpretado, em seu conjunto, como um protesto contra as quatro regras estabelecidas pelo Discours de la méthode de Descartes" (2003, p.31). A primeira regra cartesiana "de nada incluir em meus juízos que não se apresentasse tão clara e tão distintamente a meu espírito, que eu não tivesse nenhuma ocasião de pô-lo em dúvida" (DESCARTES, 1979 p.37/38), já é claramente contrária ao ensaio, no qual o dualismo entre empírico e inteligível não é admissível e no qual a dúvida não é apenas um subsídio para dar à ciência uma base mais sólida.

A segunda regra, a partir da qual Adorno começa sua crítica, diz respeito à divisão dos objetos em "tantas parcelas quanto possíveis e quantas necessárias fossem para melhor resolver suas dificuldades" (DESCARTES, in: ADORNO, 2003, p. 31). Para Adorno, essa análise dos elementos teria influenciado os esquemas conceituais da estrutura do $\operatorname{Ser}^{9}$ e também a diferenciação entre forma e conteúdo ${ }^{10}$. Essa hipostasia dos elementos de análise não cabe ao ensaio devido à sua constituição em ação recíproca entre forma e conteúdo e "não tolera nem a questão dos elementos nem a dos elementares" (ADORNO, 2003, p.32).

Contrário à terceira regra, de que os pensamentos devem ser conduzidos "começando pelos objetos mais simples e mais fáceis de conhecer, para subir, pouco a pouco, como por degraus, até o conhecimento dos mais compostos" (DESCARTES, in: ADORNO, 2003, p.32), o ensaio parte sempre do mais complexo. "A quarta regra cartesiana, 'fazer em toda parte enumerações tão completas e revisões tão gerais que se esteja certo de nada omitir'” (ADORNO, 2003, p.33), é correspondente a um princípio sistemático ao qual o ensaio também resiste. $\mathrm{O}$ ensaio só poderia realizar essa revisão geral e exaustiva se o objeto se entregasse sem reservas ao exame do conceito, tornando possível a sua exposição numa cadeia de exposições. Isso evidencia uma exigência de continuidade para o pensamento que prejulga o objeto numa coerência harmônica, própria da filosofia da identidade.

O ensaio não segue a ciência, nem a teoria e, embora se diferencie da arte pelos conceitos e pela despretensão de aparência estética, nele a forma é sempre uma categoria estética. Não é, como diria Lukács, que o ensaio seja uma forma artística ${ }^{11}$, mas sim que toda forma é estética. Quando Adorno diz que o ensaio se "rebela esteticamente contra o método mesquinho" (2003, p.34), ele também está dizendo que se rebela enquanto forma, porque a forma é uma categoria estética e a reflexão dessa categoria de forma distinta da arte sempre se 
desenvolve problematicamente. Na Teoria Estética, Adorno explica que a forma estética se entrelaça com o conteúdo e deve ser concebida "não só contra ele, mas através dele, para não ter de ser vítima daquela abstração pela qual a estética da arte costumava aliar-se" (1970, p.162).

Essa abstração é responsável pela separação entre conteúdo e forma evidente nas quatro regras do método mesquinho de Descartes. A forma mostra que Adorno critica a teoria da totalidade abstrata, mas ainda desenvolve uma teoria da totalidade, apesar de não afirmá-la, uma vez que o ensaio parte da realidade fragmentada para encontrar sua unidade nas próprias fraturas. O ensaio ainda é totalidade, porém, não é total. Não há identidade entre pensamento e coisa, mas nele existem forma e conteúdo em ação recíproca. O ensaio tem sua totalidade na unidade do objeto própria dos conflitos antagônicos do próprio objeto. "O ensaio deve permitir que a totalidade resplandeça em um traço parcial, escolhido ou encontrado, sem que a presença dessa totalidade tenha de ser afirmada" (ADORNO, 2003, p.35). Ele deve deixar que a totalidade apareça enquanto unidade dos contrários do objeto. Este está sempre em conjunto com toda a experiência que acolhe, de maneira que a contradição permaneça. Não há teoria da identidade, mas da não-identidade entre os contrários, que compõem e que são acolhidos pelo objeto.

O ensaio, que se movimenta nessa mediação não identificadora entre natureza e pensamento, toma de empréstimo a autonomia da arte no sentido que, assim como ela, apreende histórica e logicamente a contrariedade das próprias coisas. A autonomia da arte é um processo histórico que se evidencia no desenvolvimento da sociedade burguesa ${ }^{12}$. A arte começa a se desprender da vida como uma reação de proteção contra a lógica capitalista. Esse fenômeno de interiorização da arte em si mesma (verdade) pode acarretar fenômenos como o fascismo (inverdade). Nesse sentido, a revolta está no ensaio como uma força de rompimento com a pretensão de uma totalidade abstrata, assim como está na arte quando ela se apresenta como contrária à concepção de essência. Tanto no ensaio quanto na arte a revolta não deixa de lado a pretensão de uma totalidade, mas a ressitua em uma unidade mediada pelo rompimento com a ilusão. Para Adorno, a obra de vanguarda destrói a ilusão, admitindo em si a contraposição entre verdade e não verdade. Rompe, portanto, com essa ilusão de reconciliação entre homem e natureza. Por isso, a incompreensão da obra de arte de vanguarda. $\mathrm{O}$ que o receptor aceita como arte é inadequado para compreender a arte inorgânica ${ }^{13}$. Nesse sentido, o ensaio também é recebido com estranhamento porque o que a filosofia acadêmica aceita como filosofia é inadequado para compreender a filosofia transformada. 
Segundo Adorno, a única forma da dialética discorrer sobre si mesma é na forma do ensaio, porque ele é o próprio movimento da dialética na contradição não-identificável dos conceitos em verdade e inverdade. O idealismo falou em "método dialético" porque a dialética era apenas um mecanismo, ou mesmo um método para tratar de algo maior. "Por isso, o ensaio é mais dialético que a própria dialética" (ADORNO, 2003, 39). O ensaio toma a lógica hegeliana ao pé da letra, pois, nela, forma e conteúdo não se separam. Para o filósofo crítico de Frankfurt, essa inseparabilidade entre forma e conteúdo é própria da dialética e não de um método. Para o dialético e para a dialética não há nada antes da relação. A própria relação, ou o próprio modo de relação entre as coisas, os conceitos e os pensamentos, são a forma lógica que determina e é determinada pelo conteúdo lógico. Em termos hegelianos podemos dizer que me elevando ao conceito eu entendo as estruturas do pensamento e a própria lógica do mundo. A verdade se abre continuamente, e a "pretensão da singularidade da verdade deve ser tomada literalmente até que sua inverdade torne-se evidente" (ADORNO, 2003, p.39). Isso significa que cada aspecto tratado no ensaio, na pretensão (literária) da verdade singular, é irresoluto e audaciosamente antecipa outras questões. Assim, essas incompletudes audaciosas atraem os detalhes inverdadeiros, os detalhes da negação de cada aspecto. Nessa movimentação, "a inverdade, na qual o ensaio conscientemente se deixa enredar, é o elemento de sua verdade" (2003, p.39).

O tema do ensaio é a relação entre primeira natureza (natureza) e segunda natureza (cultura). Nessa relação, a verdade e a inverdade, a natureza e a cultura, estão em constante movimento dialético. Como já dito, o ensaio toma primeiramente e literalmente a singularidade da verdade (como primeira natureza) até que sua inverdade (como segunda natureza - cultura) torne-se evidente. No entanto, como o ensaio vai contra a ideia do primordial ou original, ele não pode entender a cultura a partir da natureza e também não a inverdade a partir da verdade (mesmo que tenha que partir dela). Nessa recusa, a cultura reconhece sua essência natural e toma consciência de si como primeira natureza. Assim, a verdade do ensaio move-se através de sua inverdade, ou seja, "o ensaio mergulha nos fenômenos culturais como numa segunda natureza, numa segunda imediatidade, para suspender dialeticamente, com sua tenacidade, essa ilusão" (2003, p.39). Desta forma, compreendemos que a oposição entre natureza e cultura não poupa o pensamento, justamente porque essa oposição não existe como natureza versus pensamento.

Segundo Adorno, a essência natural da própria cultura perpetua-se até hoje como mito. Aqui seria interessante retornarmos mais uma vez às ideias proferidas pelo autor na Dialética 
do Esclarecimento. Lá ele cita Schelling para dizer que a arte sempre foi prioridade face o conhecimento conceitual para a expressão da totalidade. Schelling diz que a arte é o lugar aonde a ciência quer chegar, pois, "enquanto expressão da totalidade, a arte reclama a dignidade do absoluto" (ADORNO \& HORKHEIMER, 1985, p.32). Nessa doutrina a representação artística supera a separação entre imagem e signo, entre o modo de exposição e a coisa exposta. O homem burguês, filho da desagregação social, a qual acompanha e personifica toda a realidade fragmentada vigente, só muito raramente pode confiar nesse poder da arte, ele passa a confiar na fé. O diagnóstico proferido por Adorno é o de que a fé protestante, na esperança de reconciliação entre espírito e vida, só fez ressaltar sua incoerência com o saber. Dessa maneira, a fé se apresenta como verdade nessa ilusão, na inverdade de que o saber seria limitado para falar da totalidade.

A fé se prende ao saber como sua afirmação e também como sua negação e nisso ela perpetua a separação na luta própria com uma miséria real. A fé perpetua e apresenta o fanatismo que consiste na sua inverdade. A má consciência da fé é sua segunda natureza, sua inverdade que passa a ser compreendida como primeira natureza e, portanto, como sua própria verdade. É por isso que o esclarecimento, na medida em que tentou libertar o homem e substituir o mito pelo saber, recaiu no mito, que é a fé. “O mito já é esclarecimento, e o esclarecimento acaba por se reverter à mitologia" (ADORNO \& HORKHEIMER, 1985, p.15). E na Teoria Estética, Adorno profere: "O moderno é um mito voltado contra si mesmo" (1970, p.35)

O ensaio, sendo assim, pode ser entendido também como uma negação do mito, e com o assunto da fé ele pode voltar a se referir à necessidade do esclarecimento no âmbito de uma emancipação do sujeito frente às regularidades em que ele mesmo se emaranhou. O ensaio é a revolta do moderno contra sua própria definição paradoxal. "O objeto do ensaio é, porém, o novo como novidade, que não pode ser traduzido de volta ao antigo das formas estabelecidas" (ADORNO, 2003, p.42). A novidade que é o ensaio inclui sua revolta e a perpetua quando destrói o mito e permite a compreensão da própria modernidade. A revolta do ensaio não permite que ele leve adiante as heranças que são por ele mesmo destruídas,

[...] o novo resulta do processo histórico, que dissolve primeiro a tradição específica e, em seguida, toda e qualquer tradição, assim o Moderno não é nenhuma observação que se deixaria corrigir, regressando a um terreno que já não existe e não mais deve existir (1970, p.35).

Enquanto crítica imanente da totalidade, o ensaio é "a forma crítica par excellence" (2003, p.38), ele se relaciona mediante seu tema num perpetuar da dialética negativa e toma o 
conceito como um antídoto contra toda a maldição da identidade, do originário e dos pontos de vista. Toda a argumentação traçada nessa segunda parte do artigo tentou tornar evidente que "Forma e crítica convergem" (1970, p.166), mediante a abordagem do ensaio como revolta e mostrando que a revolta está no ensaio. Em nenhum momento equiparamos a revolta à crítica, mas sim tentamos evidenciar os pontos que aliam a revolta à crítica em Adorno. Até aqui o ensaio e sua revolta se mostraram como formas críticas, a crítica tem sua raiz na revolta da filosofia transformada em relação à filosofia tradicional.

\section{Adorno versus Hegel}

Há de se considerar a riqueza da argumentação de Adorno para uma filosofia mais coerente com relação à experiência. A argumentação do texto presente tentou abordar alguns dos temas mais admiráveis desenvolvidos por Adorno dentro da necessidade de se aceitar o ensaio como a forma crítica própria de uma filosofia transformada. O ponto de partida para pensar o ensaio como forma crítica foi a revolta com que ele se dirige à filosofia idealista da identidade. Esta teria, segundo Adorno, desenvolvido uma unidade ilusória entre ciência e arte. Mostramos a compreensão de Adorno a respeito da filosofia da identidade como uma dialética positiva responsável pela dissolução total dos antagonismos. As críticas daí decorrentes, ao positivismo e à fenomenologia, por exemplo, foram também por nós apresentadas na esteira de uma crítica fundamentalmente dialética.

Nesse contexto, o ensaio salienta o parcial sem a pretensão de extrair dele algo de universal como verdadeiro. $\mathrm{O}$ ensaio não tem a intenção de trazer à tona a consciência da identidade. Justamente porque, para o seu procedimento, ela já se tornou impossível, o ensaio "leva em conta a consciência da não-identidade" (2003, p. 25). A crítica de Adorno à filosofia de sistema em especial dirigida a Hegel é importante para a época e para a constituição de toda sua teoria, assim como para a admirável crítica desenvolvida para a nova fenomenologia. O cerne de sua crítica é dirigido à impossibilidade de identificar o idêntico ao não idêntico, o sujeito ao objeto. Esse pensamento identificador não permitiria a não-identidade.

Entretanto, uma leitura mais atenta nas considerações do próprio Hegel poderia nos levar a pensar numa compreensão limitada, por parte de Adorno, do terceiro momento da dialética positiva, a qual ele tanto critica. Portanto, a revolta mais profunda do ensaio apresenta uma limitação para a própria crítica. Na Ciência da Lógica, encontramos uma excelente definição para o terceiro momento do silogismo ou ainda para o próprio absoluto:

A análise do início daria assim o conceito da unidade do ser e do não-ser - ou, na forma refletida, da unidade do ser distinto e do ser indistinto - ou da identidade da 
identidade e da não identidade. Esse conceito poderia ser considerado como a primeira, a mais pura e a mais abstrata definição do absoluto (HEGEL, 2011, p.57).

Parece claro que não há uma identificação total, que a unidade não supera por completo a diferença. Na forma refletida, a unidade do Ser compreende o distinto, a não identidade permanece, não se dissolve. Se assim fosse, na unidade do ser distinto e do ser indistinto haveria apenas identidade da identidade ou apenas identidade da não identidade e não, como nas palavras de Hegel, identidade da identidade e da não identidade. Uma abordagem dialética compreenderia que o terceiro momento do silogismo é um momento em que, sim, como Adorno considerou, a identidade é posta em primazia. Todavia, mesmo que a identidade esteja no ápice ela não consegue fazer com que a não identidade desapareça, nisso consiste a Aufhebung: ao mesmo tempo em que algo é superado, algo é guardado. Pensemos na relação entre sujeito e objeto como exemplo: o terceiro momento do silogismo é, sem dúvida, identidade, porém, identidade entre sujeito e objeto unidos (identidade da identidade) e, ao mesmo tempo, identidade entre sujeito e objeto separados (identidade da não identidade). O movimento dialético conserva as duas coisas ao mesmo tempo, unidade e diferença.

A interpretação do próprio Adorno sobre a citação de Hegel referida acima é a de que há, na negação da negação, uma primazia do sujeito porque sujeito e objeto seriam equiparados e o absoluto não poderia ser outra coisa que não o sujeito. Além do mais, quando ele diz que o particular determinável é definível pelo espírito, ele está dizendo que Hegel equipara o particular ao universal, o que parece impossível depois de uma interpretação coerente. As palavras de Adorno são as seguintes:

O filosofar hegeliano sobre o conteúdo tinha por fundamento e por resultado o
primado do sujeito ou, segundo a célebre formulação da consideração introdutória
da Lógica, a identidade entre a identidade e a não identidade. Para ele, o particular
determinado era definível pelo espírito porque sua determinação imanente não devia
ser outra coisa senão espírito $(2009$, p.15).

Essa citação coloca parte da revolta de toda a filosofia de Adorno frente aos nossos olhos e instiga nossos pensamentos. Estaria o filósofo crítico de Frankfuhrt, como afirma Henrich, trabalhando apenas com o mínimo inventário de todo o hegelianismo, apenas com as implicações de troca entre Universal - Particular e Sujeito - Objeto? ${ }^{14}$ A revolta inicial contra a filosofia de Hegel como uma filosofia da identidade, que ganha o teor de verdade unilateral por considerar apenas uma das partes do enunciado, parece mesmo injusta. O conteúdo especulativo deve ser entendido como um espelhamento da afirmação que se afirma e da negação que nega a afirmação e a própria negação, ao mesmo tempo. "A injustiça mais 
comum contra o conteúdo especulativo é torna-lo unilateral, isto é, ressaltar apenas um dos enunciados nos quais ele pode ser dissolvido" (HEGEL, 2011, p.81). Ainda, segundo Hegel, seria melhor falar em inseparabilidade do que unidade, mas ele usa o termo unidade porque só nela a afirmação pode ser incluída. Para ele, o resultado inteiro, o último momento do silogismo, o verdadeiro como devir "não é a unidade meramente unilateral" (HEGEL, 2011, p.82), mas sim a subsistência do movimento especulativo entre ser e nada, universal e particular, sujeito e objeto. Portanto, "a unidade designa ainda mais do que a identidade de uma reflexão subjetiva; ela é especialmente tomada como a relação que decorre da comparação da reflexão exterior. Na medida em que essa encontra em dois objetos distintos o mesmo" (HEGEL, 2011, p.81).

A dialética negativa, que está como nas entranhas do desenvolvimento ensaístico, se caracteriza pela impossibilidade de síntese (identidade da identidade e da não identidade), porque na síntese estaria supostamente a tão temida identificação. Porém, não seria possível pensar que a crítica de Adorno a uma suposta superação total da identidade em relação à não identidade acaba por criar outra superação total, a da não identidade sobre a identidade? Adorno não estaria, portanto, reduzindo o Universal ao Particular, o Sujeito ao Objeto? Para ele, nos seu texto Aspectos (1963), a dialética hegeliana tem um potencial crítico que vai além dela mesma, porque existe um momento empírico que não é subsumido pelo espírito ${ }^{15}$. Daí a sua tese de primado do objeto, onde a negação não pode ser equiparada a nada exterior a ela mesma ${ }^{16}$, mas necessita do entrelaçamento com o sujeito. Qual a diferença entre a tese de primado do sujeito de Hegel e a tese de primado do objeto em Adorno?

A natureza do homem o impulsiona para o campo de cisão, a sua capacidade de pensar o leva para além da imediatez. Assim, é plausível que a grande importância da subjetividade esteja também na negação. Para Adorno, a crise é essencial, mas parece que quando a tríade (afirmação, negação, negação da negação) não se completa, a própria subjetividade sucumbe. A negação é essencial, coloca a dor, o desespero e com ela surge a necessidade de superação e um novo ciclo. Sem essa possibilidade não há sequer subjetividade, mas apenas um conceito formal anterior e superior a qualquer subjetividade. O novo não pode estar exclusivamente no conflito, porque nele não há nada de novo propriamente dito, o conflito é a própria coisa, o próprio objeto, a própria experiência. Como essa dor gerada do disforme não é mais superada, não se vê mais um futuro possível.

\section{Considerações finais}


A compreensão do ensaio em Adorno é crítica adequada às exigências da filosofia transformada, entretanto, como tentamos mostrar, a revolta contra o sistema é fruto possível de uma compreensão limitada da filosofia hegeliana. Os avanços da dialética negativa para com uma filosofia transformada, assim como alguns dos pontos mais importantes abordados por Adorno, foram por nós aqui contemplados e reconhecidos. O último tópico do texto teve como objetivo instigar uma reflexão sobre as raízes da revolta protagonizada pelo ensaio.

Uma possível interpretação de um dos poemas mais belos de Baudelaire poderia nos levar a diagnosticar que Adorno, na ousadia de amar o disforme, acabou por jogar o eterno no rio do inferno, impossibilitando o encontro com o que "há de poético no histórico, de extrair o eterno do transitório" (BAUDELAIRE, 1996, p. 25). É certo que Adorno queria o contrário com o ensaio, não "procurar o eterno no transitório, [...] mas sim eternizar o transitório" (ADORNO, 2003, p.27). Porém, parece que tanto eternizar o transitório quanto extrair o eterno do transitório é impossível na filosofia crítica de Adorno, uma vez que o infinito foi condenado e o transitório se enclausurou na dor. Repetimos que a sua compreensão sobre o ensaio e a nova filosofia é brilhante e coerente com a situação fragmentária da época, porém, queremos instigar a reflexão a respeito de uma crítica limitada à dialética positiva que permite identificar alguns dos limites da própria dialética negativa. Finalizamos com o poema $O$ irremediável na íntegra:

Uma Idéia, uma Forma, um Ser / Vindo do azul e arremessado / No Estinge plúmbeo e enlodaçado / Que o olho do Céu não pode ver; // Um Anjo, viajante imprudente que ousou amar o que é disforme / Dentro de um pesadelo enorme / A debater-se na corrente // E a lutar, angústias sombrias! Contra o refluxo mais feroz,/ Que como um louco ruge a sós/ E faz na treva acrobacias;// Um prisioneiro do bruxedo / Em suas frívolas manobras / Para evitar répteis e cobras, / Tateando a lâmpada e o segredo; / Um réu a descer sem lanterna, / Rente a um abismo cujo odor / Trai a fundura e o frio horror / De uma oscilante escada eterna, // Onde velam monstros horríveis, / Cujos fosfóreos olhos fazem / Mais escura a noite em que jazem / E onde eles só ardem visíveis; / Um barco no pólo insulado, / Como num laço de cristal, / Buscando por que onda fatal/ Foi nesse cárcere atirado; // - Claros emblemas, traços reais / De uma fortuna atroz e vã, / Como a dizer-nos que Satã / Faz sempre bem tudo o que faz// Conversa a dois, clara e sombria, / Espelho que a alma em si procura/ / Fonte do Ser, límpida e impura, / Onde pulsa uma estrela fria, / Farol irônico, infernal, / Archote aceso a Satanás, Consolo e glórias sem iguais / - A consciência dentro do Mal! (BAUDELAIRE, 1985, p. 311). 


\section{NOTAS}

${ }^{1}$ Doutoranda em Filosofia pela Universidade Pontifícia Católica do Rio Grande do Sul (PUC-RS). Bolsista Capes - PROSUP. E-mail: grabrielansouzaa@ hotmail.com.

${ }^{2}$ Ver em ADORNO, Dialética Negativa, 2009, p.16.

${ }^{3}$ Ver em ADORNO, Dialética Negativa, 2009, p.92.

${ }^{4}$ É interessante notar com Adorno que, ao mesmo tempo em que Heidegger continua propondo uma linguagem científica, ele cai na armadilha do significado. A esse respeito ver o ensaio de Adorno intitulado Parataxe na poesia tardia de Hölderlin (1963), onde, partindo de uma crítica ferrenha a Heidegger, o autor deixa claro que "O caminho acompanhado pela negação de significado é o caminho para o conteúdo verdadeiro" (ADORNO, 1992, p.112). O conteúdo verdadeiro é um conceito que aparece inclusive na Teoria Estética (1968) e que se reporta ao conceito de poetizado desenvolvido por Benjamin em Dois poemas de Hölderlin (2013, p.582).

${ }^{5}$ Ver em ADORNO, Dialética Negativa, 2009, p.13 e 17.

${ }^{6} \mathrm{Na}$ analítica dos conceitos da Crítica da Razão Pura, Kant diz que os conceitos se referem a qualquer representação de um objeto ainda não determinado. O conceito, só é conceito "na medida em que se acham contidas nele outras representações, por intermédio das quais se pode referir a objetos" (1994, p.103). Apesar da crítica é preciso notar que, na compreensão dos conceitos a partir do processo em que são gerados, Kant é admirável para Adorno.

${ }^{7}$ Ver em ADORNO \& Horkheimer. Dialética do Esclarecimento, 1970, p.38.

${ }^{8}$ Esse termo foi usado anteriormente por Benjamin na sua obra Origem do drama trágico alemão, publicada em 1928. O conceito de constelação evidencia um possível platonismo convertido em objetivismo radical, segundo Benjamin: "[...] o conjunto de conceitos utilizados para representar uma ideia atualiza essa ideia como configuração desses conceitos". As ideias são o ordenamento objetivo dos fenômenos, as ideias os ordenam em interpretação objetiva. A ideia é definitivamente diferente dos objetos, as ideias não são como conceitos ou leis das coisas, elas "se relacionam com as coisas como as constelações com as estrelas" (BENJAMIN, 1984, p.56).

9 Uma dessas formas de organização do Ser pode ser por nós evidenciada no conceito de quadratura de Heidegger. Essa estrutura de quatro elementos consiste em: terra, céu, mortais e imortais "Cada coisa leva a perdurar a quadratura em cada duração da simplicidade de Mundo” (HEIDEGGER, 2012, p.158).

${ }^{10}$ A esse respeito Adorno elogia a forma análoga "com que Kant tratou as obras de arte e os organismos, embora ao mesmo tempo os tenha diferenciado" (2003, p.31) sem cair no obscurantismo romântico de submeter a arte aos mecanismos da natureza. Adorno é mais claro nessa referência a Kant no seu texto Observações sobre o pensamento filosófico (1964), quando diz que "passividade e atividade não vêm a ser de jeito nenhum separadas entre si de modo administrativo, como se poderia pensar a partir da arquitetura exterior à obra" (1995, p.17).

${ }^{11}$ Ver em ADORNO, Ensaio como forma, 2003, p.18.

${ }^{12}$ Ver em BÜRGUER, II. Sobre o problema da autonomia da arte na sociedade burguesa, 2012, p.73 a 104.

13 Segundo Peter Bürguer, as obras orgânicas são as obras simbólicas, nas quais a unidade do geral e do particular é estabelecida sem mediação. As obras inorgânicas são as obras alegóricas (tais como as de vanguarda), nas quais o tipo de unidade próprio das obras orgânicas é negado a favor de uma unidade mediada. "A obra de vanguarda não nega a unidade como tal (por mais que os dadaístas tenham intencionado coisa semelhante), mas um determinado tipo de unidade, a relação entre parte e todo que caracteriza a obra de arte orgânica" (2012, p.106).

14 Ver em HENRICH, Negativ Dialektik, 1967, p.2.

${ }^{15}$ Ver em ADORNO, Aspectos, 1970, p. 32 e 33.

${ }^{16}$ Ver em ADORNO, Aspectos, 1970, p.53.

\section{REFERÊNCIAS BIBLIOGRÁFICAS:}

ADORNO, T.W. A atualidade da filosofia. Trad. Bruno Pucci. Piracicaba: UNIMEP, 2000, p.17.

Dialética Negativa. Trad. Marco Antonio Casanova; revisão técnica Eduardo Soares Neves Silva. - Rio de Janeiro: Jorge Zahar Ed.,2009.

Ensaio como forma. In: Notas de Literatura I. Trad. Jorge M. B. de Almeida. São Paulo: Duas Cidades; Ed.34, 2003. 
. Observações sobre o pensamento filosófico. In: Palavras e sinais. Trad. Maria Helena Ruschel. Petrópolis: Vozes, 1995.

Parataxis on Holderlins Late Poetry. In: Notes do Literature Volume Two. Columbia University Press, New York, 1992. . Teoria Estética. Trad. Arthur Morão. Portugal: Ed.70, 1970.

Aspectos. In: Tres estudios sobre Hegel. Trad. Victor Sanchez de Zaralo. Madrid, Taurus Ediciones, 1970.

ADORNO, T. W \& HORKHEIMER, M. Dialética do Esclarecimento: fragmentos filosóficos. Trad. Guido Antonio de Almeida. Rio de Janeiro: Jorge Zahar Ed., 1985.

BENJAMIN, W. Dois poemas de Hölderlin. Trad. Teresa revista de Literatura brasileira; São Paulo, 2013, p.585.

. Origem do drama barroco alemão. Trad. Sergio Paulo Rouanet. Brasiliense, 1984.

BAUDELAIRE, C. As Flores do Mal. Trad. Ivan Junqueira - Rio de Janeiro: Nova Fronteira, 1985.

BAUDELAIRE, C. Sobre a modernidade: o pintor da vida moderna. Rio de Janeiro: Paz e Terra, 1996.

BÜRGUER, P. II. Sobre o problema da autonomia da obra de arte e III. A obra de arte de vanguarda. In: Teoria da Vanguarda. Trad. José Pedro Antunes. São Paulo, Cosac Naify. 2012. (p.73 a 148)

DESCARTES. R. Discurso do Método. Trad. J. Guinsburg e Bendo Prado Júnior. São Paulo: Abril Cultural, 1979.

HENRICH, D. Negative Dialektik. Rezension. Frankfurt am Main: Suhrkamp Verlag, 1967.

HEGEL, G.W.F. Ciência da lógica (excertos). Trad. Marco Aurélio Werle. São Paulo, Barcarolla, 2011.

HEIDEGGER, M. A coisa. Tradução de Emmanuel Carneiro Leao. In: Ensaios e Conferências. 8 ed. Petrópolis: Vozes; Bragança Paulista: Editora Universitária São Franscisco, 2012.

KANT, I. Crítica da razão pura. Tradução de Manuela Pinto dos Santos e Alexandre Morujão. Fundação Calouste Gulbenkian, Lisboa, 1994. 